\title{
Flexural Behaviour of Recycled Waste Glass Fine Aggregate Concrete Beams
}

\author{
B. Parthiban, S. Thirugnanasambandam
}

\begin{abstract}
Glass is recycled indefinitely with none loss in quality. This paper presents various grade of concrete like $M 20$, $M 40$ and $M 60$ is the appropriately of recycled glass aggregate as an alternative for making concrete. $M 20, M 40$ and $M 60$ control concrete made with conventional fine aggregate and concrete made with glass aggregate. The properties of recycled waste glass aggregate is compared with conventional fine aggregate. For each grade M20, M 40 and M 60, six numbers of size $100 \times 100 \times 100$ millimeter cubes are cast to find out the mechanical strength for control concrete and recycled waste glass fine aggregate concrete. To study flexural behaviour, 125 $\times 200 \times 1100$ millimeter size of the beams are cast. All beams are designed as under reinforced sections. For above grade mix, three beams are made with conventional concrete and other three beams are made with recycled waste glass fine aggregate concrete. All the beams are tested for flexure. The maximum load carrying capacity, deflection, crack patterns are obtained. The experimental results are compared with finite element modelling using ANSYS software.
\end{abstract}

Index Terms-Cement Concrete, Recycled Waste Glass Fine Aggregate (RWGFA), Compressive Strength, Flexural Behaviour, Deflected Shape of Beams, ANSYS.

\section{INTRODUCTION}

The successful use of recycled waste glass aids in reducing the ecological effects of altering the environment. An increase in percentage of aggregates substitute with recycled glass aggregate ends up in reduction in concrete unit mass [1]. At the same time, the recycling is necessary for environmental protection. The world wide use of fine aggregate is incredibly high, because of the utilization in concrete [2]. At present situation the quality of river sand is demand for concrete manufacturing. Some of the alternative materials have been used already for making concrete. There are copper slag, manufacturing sand, slag, quarry dust, sea sand and rice husk dust. In this study, recycled glass aggregate is effectively used. The recycled waste glass fine mixture is employed as fine aggregate in concrete and no reaction is find out with fine particle size. Once the particle size is reduced, it contributes concrete properties leading to a visible improvement of its mechanical performance [3]. The size of glass is influenced the microstructure of the concrete and it leads to denser and less permeable concrete. Water absorption is decreased and the durability is increased with increase the glass content [4]. Hence, in this study recycled waste glass fine aggregate is effectively used in cement concrete manufacturing and tested for flexural behaviour of beams.

Revised Manuscript Received on April 12, 2019.

B. Parthiban, Research Scholar, Civil and Structural Engineering, Annamalai University, Annamalai Nagar, India (balaparthi@gmail.com)

S. Thirugnanasambandam, Associate Professor, Civil and Structural Engineering, Annamalai University, Annamalai Nagar, India (agstsai@gmail.com)

\section{EXPERIMENTAL PROGRAM}

\section{A. Cement}

OPC forty three grade is employed for the concrete manufacturing. The properties of OPC 43 grade is tabulated in Table one.

Table 1 Properties of Cement

\begin{tabular}{|c|c|}
\hline Property & Result \\
\hline Specific Gravity & 3.15 \\
\hline Fineness & $2.01 \%$ \\
\hline Standard Eubstance & $29 \%$ \\
\hline Setting Initial Stage & One hour \\
\hline Setting Final Stage & Ten hour \\
\hline Compression strength & $43 \mathrm{MPa}$ \\
\hline
\end{tabular}

\section{B. Coarse Aggregate}

Crushed stone used is angular in shape passing through twenty $\mathrm{mm}$ sieve and maintained on 4.75 millimeter IS sieve. The precise gravity of coarse combination is 2.76 and also the F.M. is 7.13.

\section{Recycled waste Glass Fine Aggregate (RWGFA)}

Recycled waste white colour glass is used as fine aggregate. Washing is necessary before recycling process to remove the impurities in the glass. For required size the waste glass is screened for immediate use. The size of the recycled waste glass size of $3 \mathrm{~mm}$ and down $3 \mathrm{~mm}$ is used. The sample of recycled waste glass fine aggregate is shown in Figure 1. The properties of recycled waste glass fine aggregate are given in Table 2. The Scanning Electron Micrograph (SEM) images of recycled waste glass fine aggregates are shown in Figure 2 . The chemical composition of recycled waste glass is tabulated in Table 3.

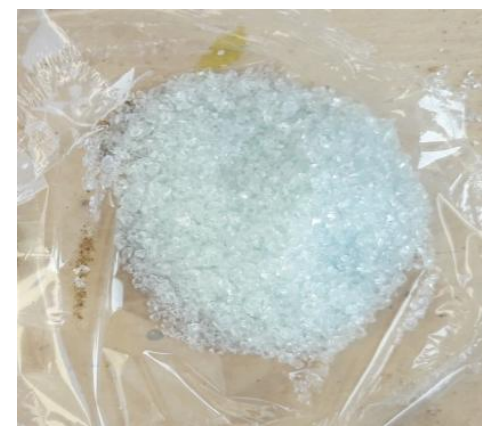

Figure 1 Glass Aggregate (RWGFA) 
Table 2 Physical Properties of RWGFA

\begin{tabular}{|c|c|}
\hline Property & Result \\
\hline Specific Gravity & 2.56 \\
\hline Size of the Aggregate & $\mathbf{3} \mathrm{mm}$ and down $3 \mathrm{~mm}$ \\
\hline
\end{tabular}
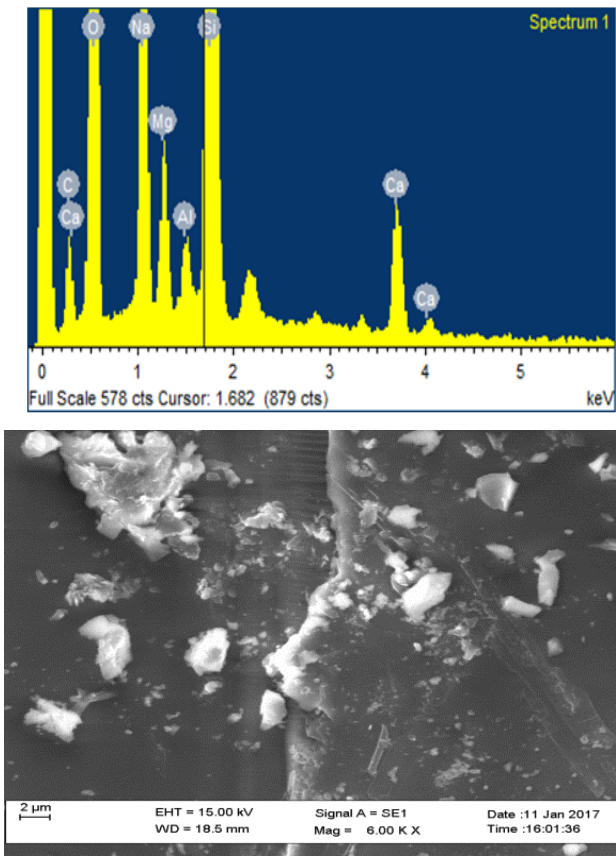

Figure 2 SEM Images of RWGFA

Table 3 Chemical Constituents of RWGFA

\begin{tabular}{|c|c|}
\hline Constituent & In Percentage \\
\hline $\mathrm{SiO}_{2}$ & 78.01 \\
\hline $\mathrm{CaCO}_{3}$ & 7.83 \\
\hline $\mathrm{Na}$ & 8.60 \\
\hline $\mathrm{MgO}$ & 1.81 \\
\hline $\mathrm{Ca}$ & 3.02 \\
\hline $\mathrm{Al}_{2} \mathrm{O}_{3}$ & 0.61 \\
\hline
\end{tabular}

\section{Admixture}

Super plasticizer (SP), Fosroc SP 430 is used. The use of chemical admixtures improves the slump loss and improves workability and durability. In this study SP of $0.7 \%$ to $1 \%$ weight of the cement is used.

\section{E. Water}

Locally available potable water which is free from organic impurities is used for this concrete manufacturing work.

\section{F. Mixing, Casting and Curing}

Various grades of mix M 20, M 40 and M 60 for cement concrete are designed for mix proportion by using IS Code 10262-2009. Cement concrete cubes, beams, RWGFA concrete cubes and RWGFA concrete beams are castas per the design mix. Addition of water in the mix to a certain the extend increases the workability but it reduce the durability. Super plasticizer is used to control the water demand in making concrete and improves the workability. The workability of latest concrete is measured by suggests that of the slump take a look at. River sand is employed for control concrete and sand is fully replaced with recycled glass aggregate for other mix. Figure 3 shows the materials
RWGFA concrete. The mix proportions of various grades for control mix made, sand as fine aggregate and RWGFA concrete made with recycled waste glass concrete are tabulated in Table 4.

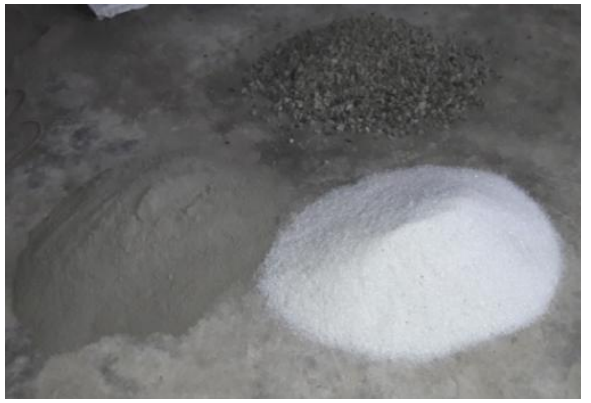

Figure 3 Materials used for RWGFA Geopolymer Concrete

Table 4 Various Grade Mix Proportions of CC and RWGFA concrete

\begin{tabular}{|c|c|c|c|c|c|c|c|}
\hline \multirow{2}{*}{$\begin{array}{l}\mathbf{G} \\
\mathbf{r} \\
\mathbf{a} \\
\mathbf{d} \\
\mathrm{e}\end{array}$} & \multirow[b]{2}{*}{ Mix } & \multirow{2}{*}{$\begin{array}{c}\mathbf{B} \\
\mathbf{i} \\
\mathbf{n} \\
\mathbf{d} \\
\mathbf{e} \\
\mathbf{r}\end{array}$} & \multicolumn{2}{|c|}{$\begin{array}{c}\text { Fine } \\
\text { Aggregate }\end{array}$} & \multirow{2}{*}{$\begin{array}{c}\text { Coarse } \\
\text { Aggreg } \\
\text { ate }\end{array}$} & \multirow{2}{*}{$\begin{array}{l}\mathbf{W} \\
\mathbf{a} \\
\mathbf{t} \\
\mathbf{e} \\
\mathbf{r}\end{array}$} & \multirow{2}{*}{$\begin{array}{c}\text { Admi } \\
\text { xture } \\
\text { In } \\
(\%)\end{array}$} \\
\hline & & & $\begin{array}{l}\text { San } \\
\text { d }\end{array}$ & Glass & & & \\
\hline \multirow{2}{*}{$\begin{array}{l}M \\
20\end{array}$} & $\mathrm{CC}$ & 1 & 2.75 & 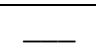 & 3.36 & 0.50 & 0.7 \\
\hline & $\begin{array}{c}\mathrm{CC}(\mathrm{R} \\
\mathrm{WGF} \\
\mathrm{A}\end{array}$ & 1 & & 2.75 & 3.36 & 0.50 & 0.7 \\
\hline \multirow{2}{*}{$\begin{array}{l}\text { M } \\
40\end{array}$} & $\mathrm{CC}$ & 1 & 1.67 & 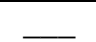 & 2.50 & 0.39 & 1.0 \\
\hline & $\begin{array}{c}\mathrm{CC}(\mathrm{R} \\
\mathrm{WGF} \\
\mathrm{A})\end{array}$ & 1 & & 1.67 & 2.50 & 0.39 & 1.0 \\
\hline \multirow{2}{*}{$\begin{array}{l}M \\
60\end{array}$} & $\mathrm{CC}$ & 1 & 1.33 & 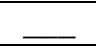 & 2.33 & 0.35 & 1.0 \\
\hline & $\begin{array}{c}\mathrm{CC}(\mathrm{R} \\
\mathrm{WGF} \\
\mathrm{A})\end{array}$ & 1 & & 1.33 & 2.33 & 0.35 & 1.0 \\
\hline
\end{tabular}

Various grade of mix M 20, M 40 and M 60, altogether thirty six cubes of size one hundred $\times 100 \times 100$ millimeter are forged to search out the mechanical strength at seven days and twenty eight days. For flexural behavior, out of six beams, three beams of size $125 \mathrm{~mm} \times 200 \mathrm{~mm} \times 1100 \mathrm{~mm}$ long are cast in cement concrete made with river sand as fine aggregate and remaining three beams are cast with RWGFA. The specimens are demoulded once twenty four hours and cured in storage tank. The specimens are tested once seven and twenty eight days of natural process.

\section{EXPERIMENTAL PROGRAM}

\section{A. Compressive Strength}

For compression test, $1000 \mathrm{KN}$ capacity of compressive testing machine is used to apply the load and the test is conducted as per IS 516-1959. The load is gradually

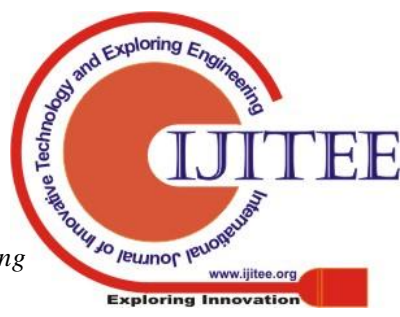


increases until the cube is failure. The maximum load taken by each specimen during the test is recorded. The mean value is the strength of cube.Test result of various grades of M 20, M 40 and M 60 mix control concrete and recycled waste glass fine aggregate (RWGFA) concrete are tabulated in Table five.

Table 5 Mechanical Strength of Cube

\begin{tabular}{|c|c|c|c|}
\hline \multirow{2}{*}{ Mix } & \multirow{2}{*}{ Code } & \multicolumn{2}{|c|}{$\begin{array}{c}\text { Mechanical Strength } \\
\text { (MPa) }\end{array}$} \\
\cline { 3 - 4 } & & $\begin{array}{c}\text { Seven } \\
\text { days }\end{array}$ & $\begin{array}{c}\text { Twenty } \\
\text { Eight days }\end{array}$ \\
\hline \multirow{3}{*}{ M 20 } & CC & 18.83 & 28.00 \\
\cline { 2 - 4 } & $\begin{array}{c}\text { CC } \\
(\text { RWGFA) }\end{array}$ & 19.02 & 29.30 \\
\hline \multirow{3}{*}{ M 40 } & CC & 35.80 & 46.60 \\
\cline { 2 - 4 } & $\begin{array}{c}\text { CC } \\
\text { (RWGFA) }\end{array}$ & 39.70 & 48.56 \\
\hline \multirow{3}{*}{ M 60 } & CC & 51.42 & 68.50 \\
\cline { 2 - 4 } & $\begin{array}{c}\text { CC } \\
\text { (RWGFA) }\end{array}$ & 56.10 & 70.16 \\
\hline
\end{tabular}

B. Test on CC Beams and RWGFA Beams under Flexure

Flexural behaviour is studied under beams of size 125 $\mathrm{mm} \times 200 \mathrm{~mm} \times 1100 \mathrm{~mm}$. The beams are designed as under reinforced sections. Three beams are made with conventional concrete and remaining three beams are made with RWGFA in concrete to obtain flexural behaviour of concrete in various grade mix of M 20, M 40 and M 60. The mix proportion and beam reinforcement details are tabulated in Table 6. For shear reinforcement $8 \mathrm{~mm}$ diameter at 150 $\mathrm{mm}$ spacing is used as two legged vertical stirrups in all beams. After 28 days in water curing, the cement concrete and RWGFA concrete beam specimens are prepared for testing. The test set up is shown in Figure 4. The test specimen is mounted in a beam testing frame of $200 \mathrm{kN}$ capacity. The beams are simply supported over a span of $1000 \mathrm{~mm}$ and subjected to two concentrated loads are applied through a spreader beam placed symmetrically on the span. The distance between the load points is 333.33 $\mathrm{mm}$. The load is applied on two points each $166.67 \mathrm{~mm}$ away from the centre of the beam towards the support. To measure the deflection, dial gauges of $0.001 \mathrm{~mm}$ least count is used. Three dial gauges are used to measure the deflections in mid span and below the load points. Load is given at the interval of every 0.5 Ton. Mechanical dial gauge is placed at centre to measure the deflection during the time of ultimate stage. Crack width, nature of crack are monitored during beam testing. First crack load is obtained by visual examination. Loading have continued up to the ultimate stage and all the measurements are recorded. Testing of beam under two points loading is shown in Figure 5. The flexural test result of M 20, M 40 and M 60 cement concrete beams RWGFA concrete beams are tabulated in Table 7.

Table 6 Mix Proportion and Reinforcement Details

\begin{tabular}{|c|c|c|c|c|}
\hline \multirow{2}{*}{ Grade } & \multirow{2}{*}{ Mix } & \multirow{2}{*}{$\begin{array}{c}\text { Mix } \\
\text { Proportion }\end{array}$} & \multicolumn{2}{|c|}{$\begin{array}{c}\text { Longitudinal } \\
\text { Reinforcement }\end{array}$} \\
\cline { 3 - 5 } & & Top & Bottom \\
\hline M 20 & CC & $1: 2.75: 3.36$ & $2-8 \#$ & $2-10 \#$ \\
\hline
\end{tabular}

\begin{tabular}{|c|c|c|c|c|}
\hline & RWGFA & $1: 2.75: 3.36$ & $2-8 \#$ & $2-10 \#$ \\
\hline \multirow{3}{*}{ M 40 } & CC & $1: 1.67: 2.50$ & $2-8 \#$ & $2-10 \#$ \\
\cline { 2 - 5 } & RWGFA & $1: 1.67: 2.50$ & $2-8 \#$ & $2-10 \#$ \\
\hline \multirow{2}{*}{ M 60 } & CC & $1: 1.33: 2.33$ & $2-10$ & $2-12 \#$ \\
& & & $\#$ & \\
\cline { 2 - 5 } & RWGFA & $1: 1.33: 2.33$ & $\begin{array}{c}2-10 \\
\#\end{array}$ & $2-12 \#$ \\
& & & \multicolumn{2}{|c}{} \\
\hline
\end{tabular}

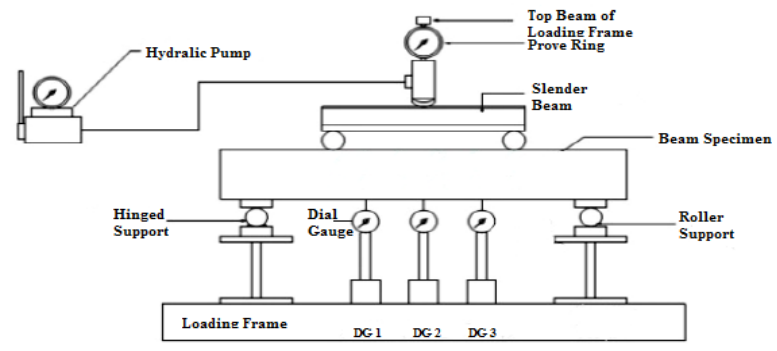

Figure 4 Test Set up of Beam

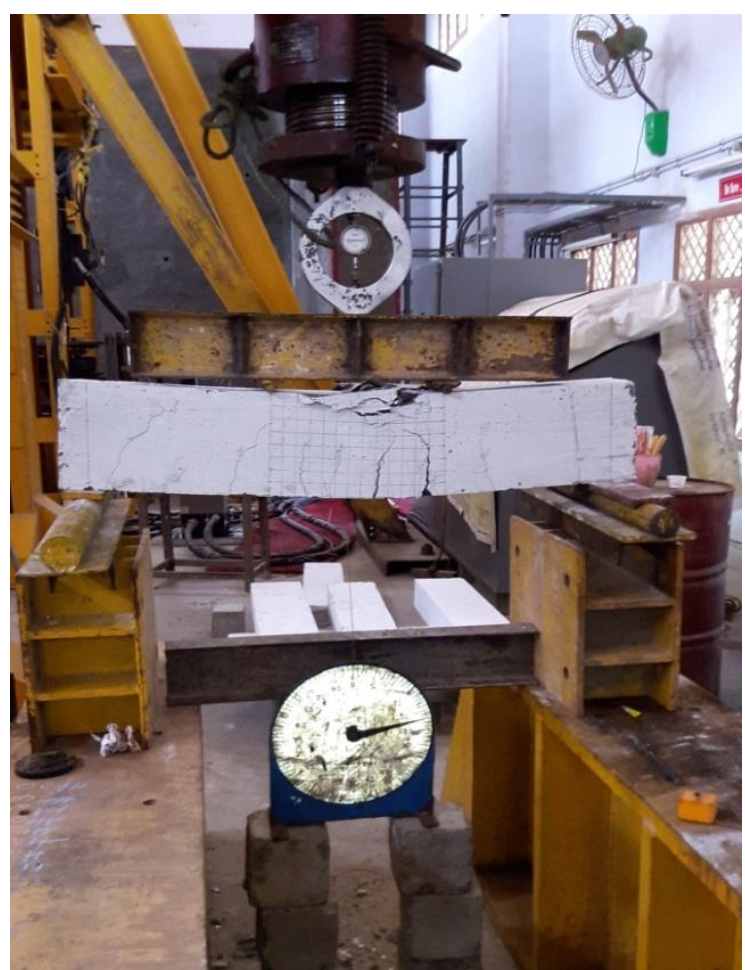

Figure 5 Testing Specimen Under Two Point Loading Table 7 Test Result of Cement Concrete and RWGFA Concrete Beams

\begin{tabular}{|c|c|l|l|l|l|l|}
\hline $\begin{array}{c}\text { Gra } \\
\text { de }\end{array}$ & $\begin{array}{l}\text { Beam } \\
\text { Code }\end{array}$ & $\begin{array}{l}\text { Load } \\
\text { Crac } \\
\text { kilo } \\
\text { Newt } \\
\text { on) }\end{array}$ & $\begin{array}{l}\text { Servi } \\
\text { ce } \\
\text { Load } \\
\text { (kilo } \\
\text { Newt } \\
\text { on) }\end{array}$ & $\begin{array}{l}\text { Yield } \\
\text { Load } \\
\text { (kilo } \\
\text { Newt } \\
\text { on) }\end{array}$ & $\begin{array}{l}\text { Ultim } \\
\text { ate } \\
\text { Load } \\
\text { (kilo } \\
\text { Newt } \\
\text { on) }\end{array}$ & $\begin{array}{l}\text { Max } \\
\text { ectio } \\
\text { nefl } \\
\text { (mill } \\
\text { imet } \\
\text { er) }\end{array}$ \\
\hline $\begin{array}{c}\text { M } \\
20\end{array}$ & CC & 40.00 & 54.33 & 80.50 & 82.50 & $\begin{array}{l}16.0 \\
0\end{array}$ \\
\hline
\end{tabular}


Flexural Behaviour Of Recycled Waste Glass Fine Aggregate Concrete Beams

\begin{tabular}{|c|c|c|c|c|c|c|}
\hline & $\begin{array}{c}\mathrm{CC} \\
(\mathrm{RWGF} \\
\mathrm{A})\end{array}$ & 50.00 & 57.00 & 82.50 & 85.50 & $\begin{array}{c}17.0 \\
0\end{array}$ \\
\hline \multirow[b]{2}{*}{ M40 } & $\mathrm{CC}$ & 37.50 & 56.68 & 80.00 & 85.00 & $\begin{array}{c}22.0 \\
0\end{array}$ \\
\hline & $\begin{array}{c}\mathrm{CC} \\
(\mathrm{RWGF} \\
\mathrm{A})\end{array}$ & 55.00 & 71.67 & $\begin{array}{c}105.0 \\
0\end{array}$ & $\begin{array}{c}107.5 \\
0\end{array}$ & $\begin{array}{c}25.0 \\
0\end{array}$ \\
\hline \multirow[b]{2}{*}{$\begin{array}{l}M \\
60\end{array}$} & $\mathrm{CC}$ & 45.00 & 63.33 & 92.50 & 95.00 & $\begin{array}{c}27.0 \\
0\end{array}$ \\
\hline & $\begin{array}{c}\mathrm{CC} \\
(\mathrm{RWGF} \\
\mathrm{A})\end{array}$ & 47.50 & 83.33 & $\begin{array}{c}122.5 \\
0\end{array}$ & $\begin{array}{c}125.0 \\
0\end{array}$ & $\begin{array}{c}29.0 \\
0\end{array}$ \\
\hline
\end{tabular}

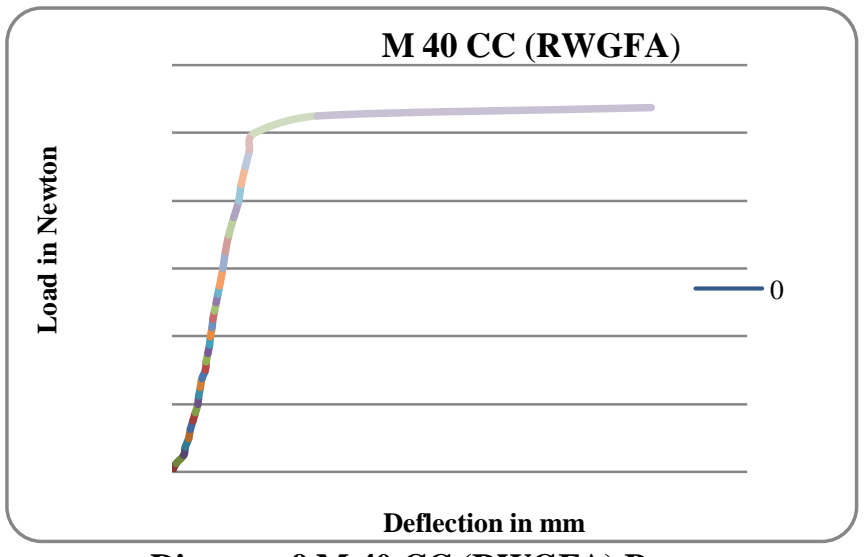

The load deflection behaviour for various mix $\mathrm{CC}$ and RWGFA concrete beams are displayed in Diagram 6 to 11 .
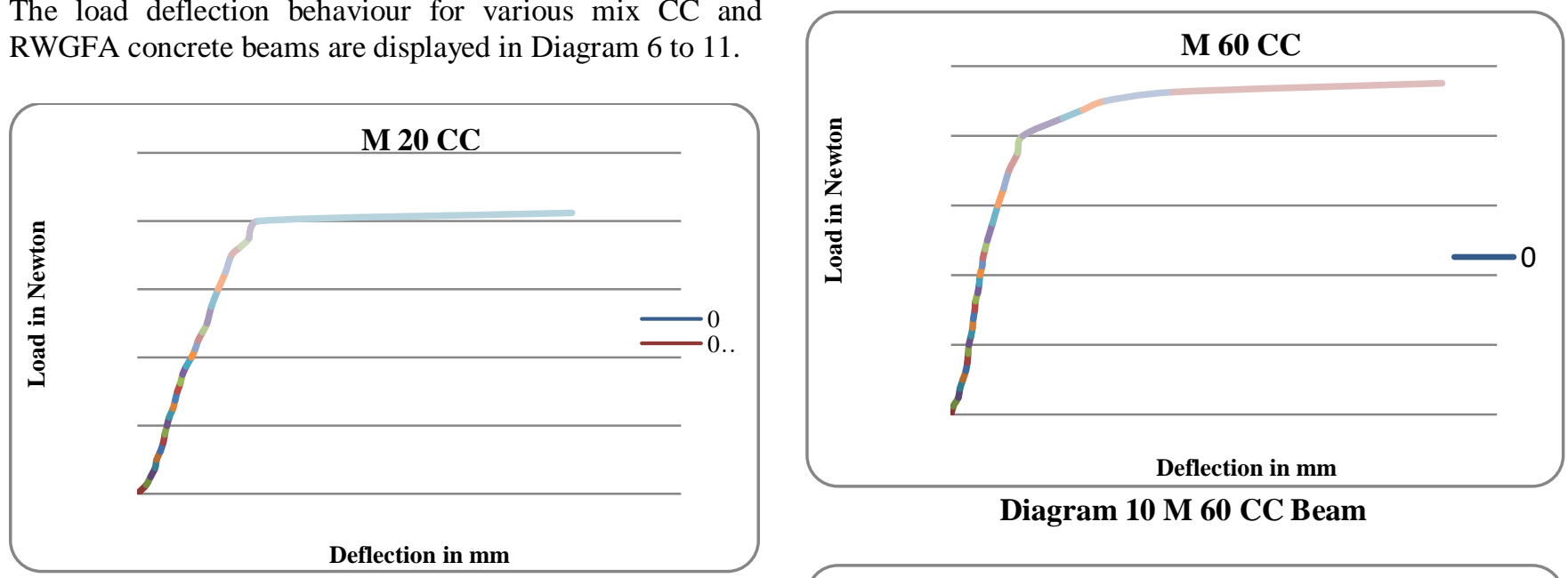

Diagram 10 M 60 CC Beam

Diagram 6 M 20 CC Beam

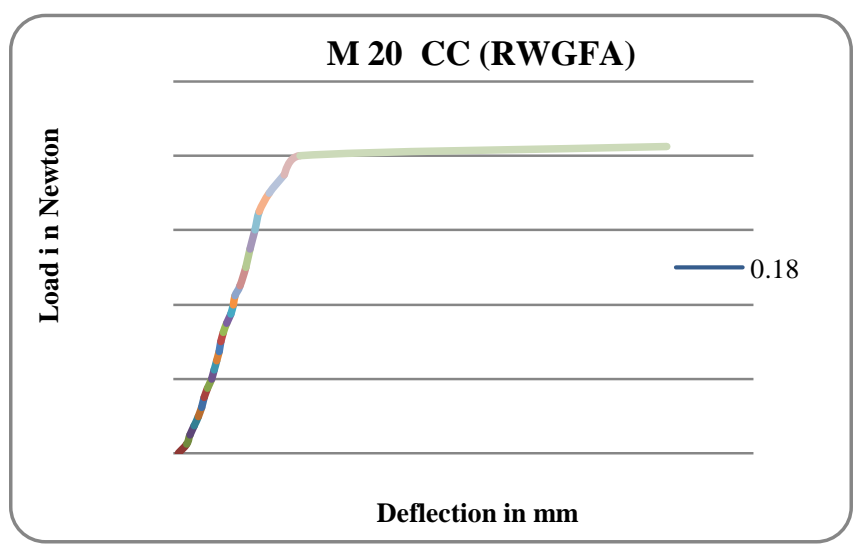

Diagram 7 M 20 CC (RWGFA) Beam
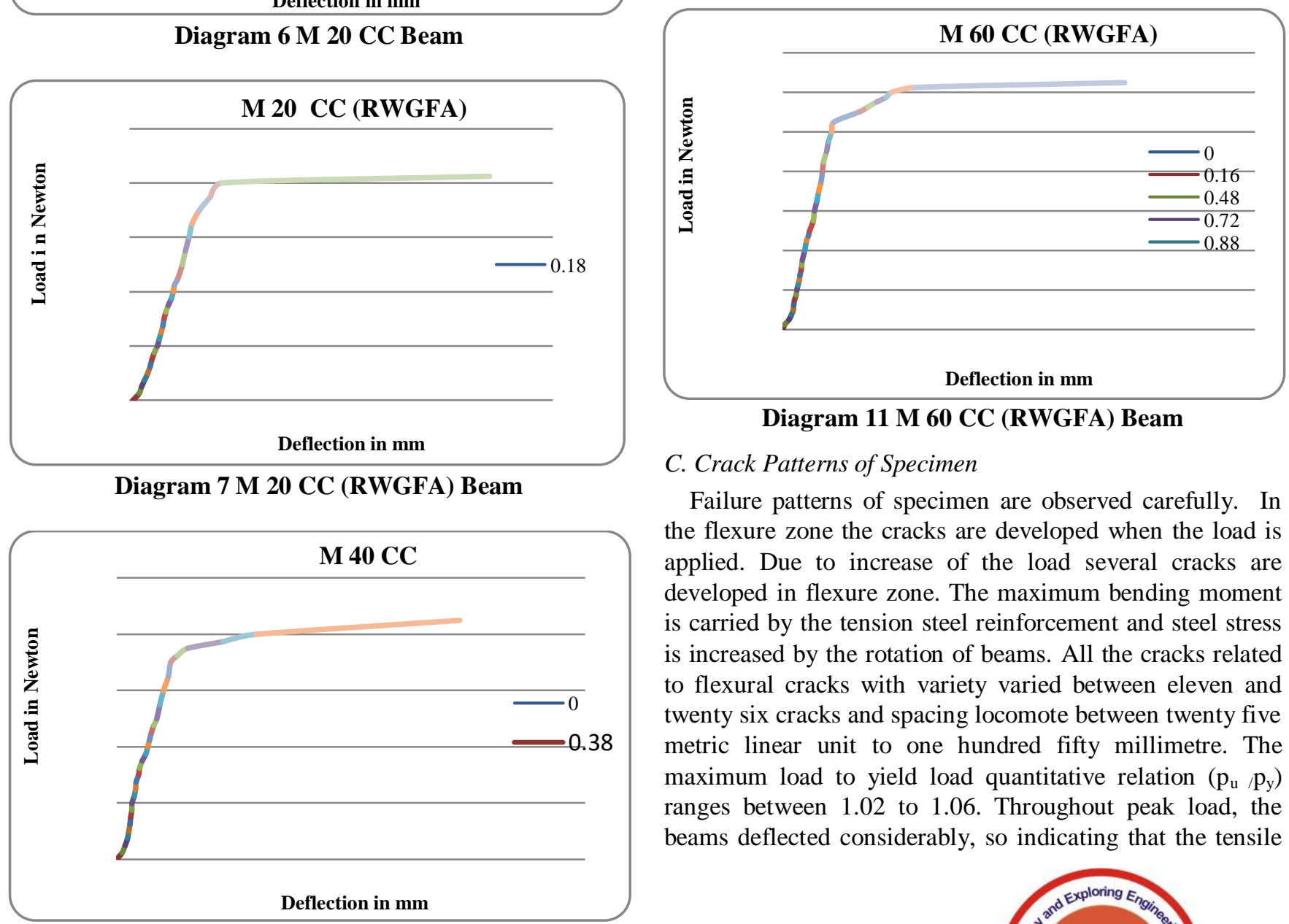

\section{Diagram 11 M 60 CC (RWGFA) Beam}

\section{Crack Patterns of Specimen}

Failure patterns of specimen are observed carefully. In the flexure zone the cracks are developed when the load is applied. Due to increase of the load several cracks are developed in flexure zone. The maximum bending moment is carried by the tension steel reinforcement and steel stress is increased by the rotation of beams. All the cracks related to flexural cracks with variety varied between eleven and twenty six cracks and spacing locomote between twenty five metric linear unit to one hundred fifty millimetre. The maximum load to yield load quantitative relation $\left(\mathrm{p}_{\mathrm{u}} / \mathrm{p}_{\mathrm{y}}\right)$ ranges between 1.02 to 1.06. Throughout peak load, the beams deflected considerably, so indicating that the tensile

Diagram 8 Load Deflection Curve of M 40 CC Beam

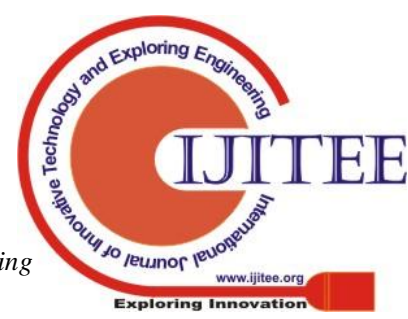


steel should have yielded at failure. Once the compression zone is crushed, the final failure of the beam occurred in the middle of buckling of steel bars. The failure mode of all beams are that typical failure of an under-reinforced concrete beams. During the test, the crack patterns are measured with crack deflection microscope and the pattern of cracks are analyzed. During the test the crack width is marked every $25 \mathrm{kN}$. The width of crack is generally increased at tension zone and the cracks are perpendicular to the beam axis. In all the beams, mostly vertical cracks are appear in bending zone and inclined cracks are appeared in shear zone. The typical crack patterns of various grade mix CC and RWGFA concrete are displayed in Figure 12 to 17.

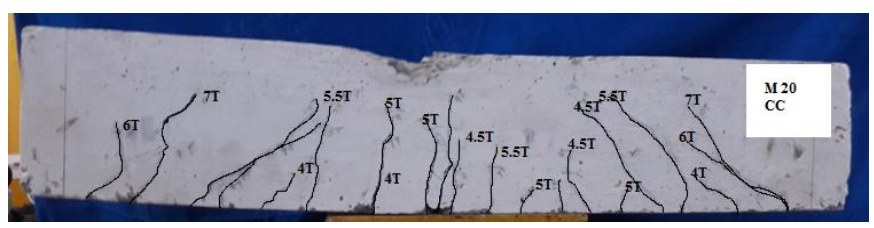

Figure 12 Crack Patterns of M 20 CC Beam

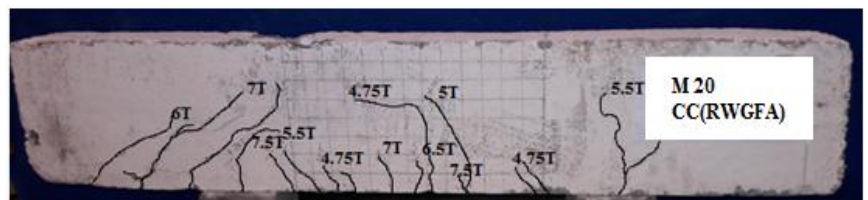

Figure 13 Crack Patterns of M 20 CC (RWGFA) Beam

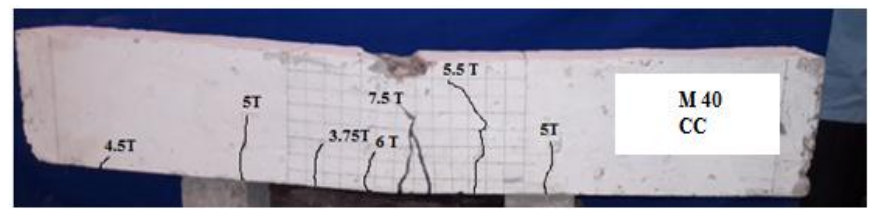

Figure 14 Crack Patterns of M 40 CC Beam

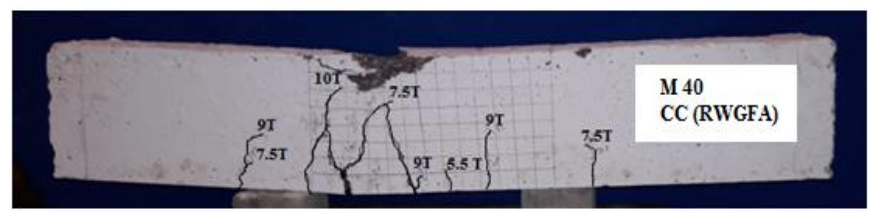

Figure 15 Crack Patterns of M 40 CC (RWGFA) Beam

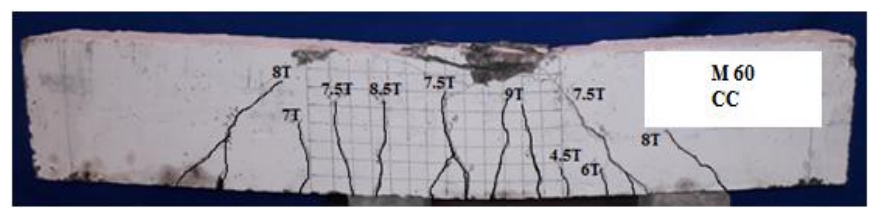

Figure 16 Crack Patterns of M 60 CC Beam

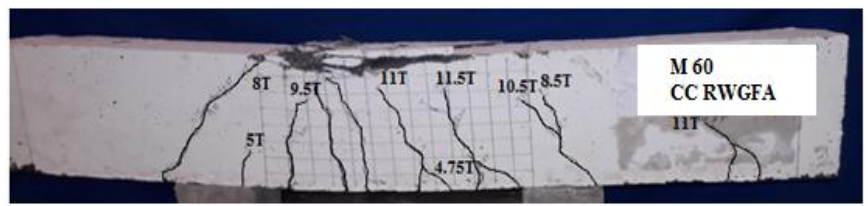

Figure 17 Crack Patterns of M 60 CC (RWGFA) Beam

\section{Ductility Behaviour of CC Beams and RWGFA Beams}

Ducttility is also outlined also because the ability of the part to deform while not important loss of resistance. The displacement ductility of various grade mix CC and RWGFA concrete is tabulated in Table 8.
Table 8 Ductility Displacement of Cement Concrete Beams and RWGFA Beams

\begin{tabular}{|c|c|c|c|c|}
\hline $\begin{array}{c}\text { Grad } \\
\text { e }\end{array}$ & $\begin{array}{l}\text { Beam } \\
\text { Code }\end{array}$ & $\begin{array}{l}\text { Minimu } \\
\text { m } \\
\text { Deflectio } \\
\mathbf{n} \\
\text { (milli } \\
\text { metre) }\end{array}$ & $\begin{array}{c}\text { Maximu } \\
\text { m } \\
\text { Deflectio } \\
\mathbf{n} \\
\text { (milli } \\
\text { metre) }\end{array}$ & $\begin{array}{l}\text { Ductilit } \\
\text { y Ratio }\end{array}$ \\
\hline \multirow[b]{2}{*}{ M 20} & $\mathrm{CC}$ & 4.46 & 16.00 & 3.59 \\
\hline & $\begin{array}{c}\text { CC } \\
(\mathrm{RWGFA} \\
\text { ) }\end{array}$ & 4.38 & 17.00 & 3.88 \\
\hline \multirow[b]{2}{*}{ M 40} & $\mathrm{CC}$ & 8.93 & 22.00 & 2.46 \\
\hline & $\begin{array}{c}\text { CC } \\
\text { (RWGFA } \\
\text { ) }\end{array}$ & 7.58 & 25.00 & 3.30 \\
\hline \multirow[b]{2}{*}{ M 60} & $\mathrm{CC}$ & 12.18 & 27.00 & 2.22 \\
\hline & $\begin{array}{c}\text { CC } \\
(\mathrm{RWGFA} \\
\text { ) }\end{array}$ & 11.18 & 29.00 & 2.59 \\
\hline
\end{tabular}

D. AnsysModelling of Beams

FEA computer code ANSYS is adopted for predicting the load displacement response of conventional, RWGFA beams. For solid 65 element the mesh was set up such that square or rectangular elements and nodes in the concrete portion of the model. For beam generation total mesh model defined 4666 nodes and 3380 elements are required. These nodes and elements follows a procedure of concrete mapped mesh modelling in which meshes are generated in even order. Free mesh modelling is the one in which the meshes are generated in random. The meshing concrete is shown in Figure 18 and the meshing reinforcement is shown in Figure 19. ANSYS results are compared with experimental results, the values are arranged in Table 9. Various grades of mix M 20, M 40 and M 60 cement concrete and RWGFA concrete beams typical deflected shapes are shown in Figure 20 to Figure 25.

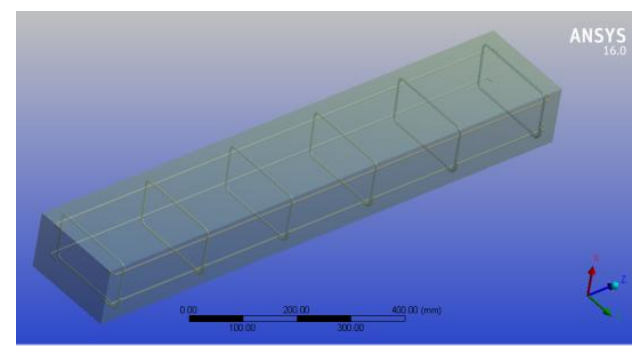

Figure 18 Meshing Concrete 


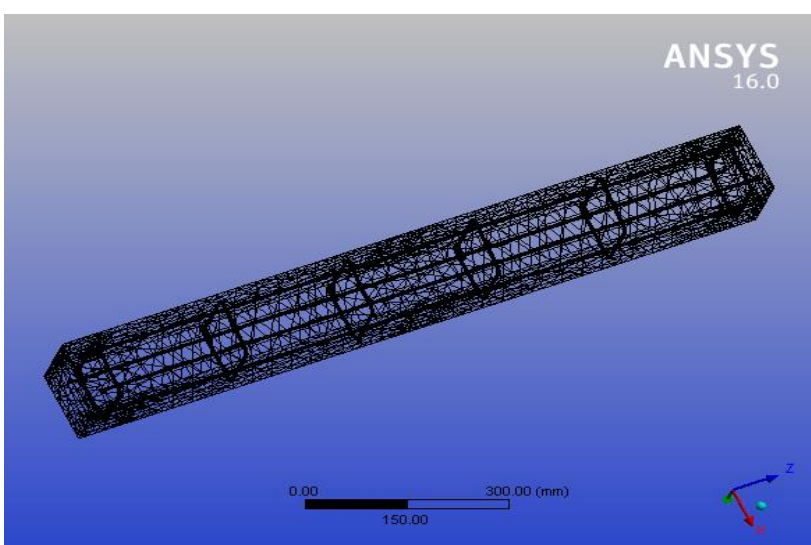

Figure 19 Meshing Reinforcement

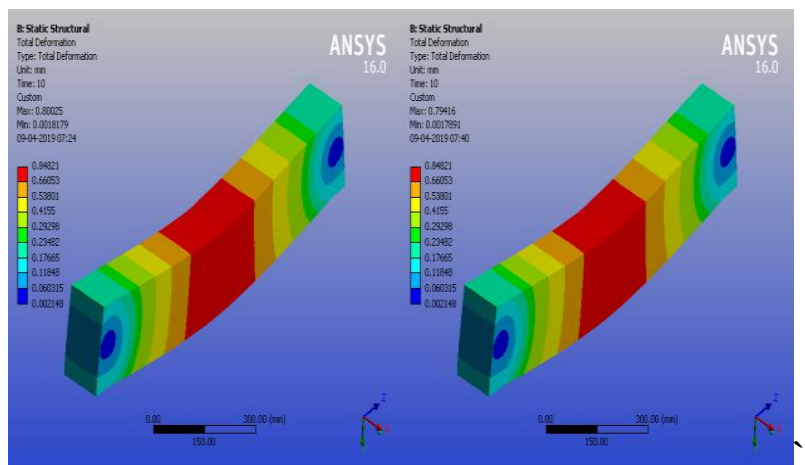

Figure 20 Deflected Shape Figure 21 Deflected Shape of M 20 CC Beam of M 20 CC (RWGFA) Beam

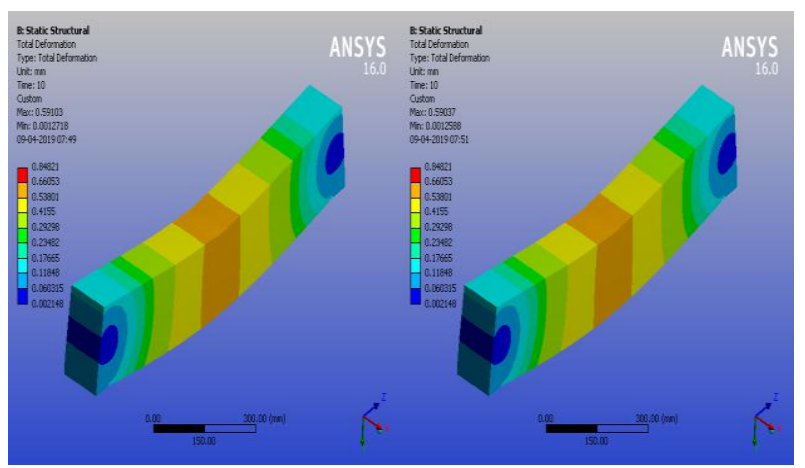

Figure 22 Deflected Shape Figure 23 Deflected Shape of M 40 CC Beam of M 40 CC (RWGFA) Beam

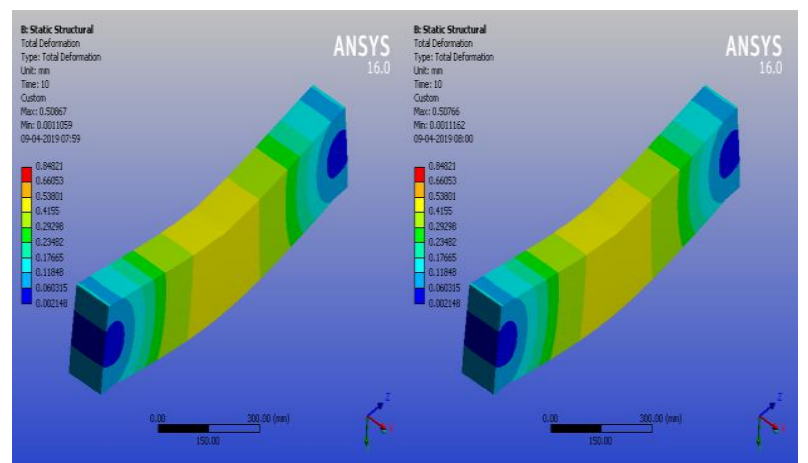

Figure 24 Deflected Shape Figure 25 Deflected Shape of M 40 CC Beam of M 40 CC (RWGFA) Beam

Table 9 Summary of Test Results for Cement Concrete and RWGFA Concrete Beams

\begin{tabular}{|c|c|c|c|c|c|c|c|}
\hline \multirow{2}{*}{$\begin{array}{l}\text { G } \\
\mathbf{R} \\
\mathbf{A} \\
\mathbf{D} \\
\mathbf{E}\end{array}$} & \multirow{2}{*}{$\begin{array}{l}\text { Beam } \\
\text { Code }\end{array}$} & \multicolumn{2}{|c|}{$\begin{array}{l}\text { Yield Load } \\
\text { (kilo } \\
\text { Newton) }\end{array}$} & \multicolumn{2}{|c|}{$\begin{array}{c}\text { Maximum } \\
\text { Load } \\
\text { (kilo } \\
\text { Newton) }\end{array}$} & \multicolumn{2}{|c|}{$\begin{array}{c}\text { Ultimate } \\
\text { Deflection } \\
\text { (millimeter) }\end{array}$} \\
\hline & & $\begin{array}{l}\text { Expe } \\
\text { rime } \\
\text { ntal }\end{array}$ & $\begin{array}{l}\text { ANS } \\
\text { YS }\end{array}$ & $\begin{array}{l}\text { Expe } \\
\text { rime } \\
\text { ntal }\end{array}$ & $\begin{array}{l}\text { ANS } \\
\text { YS }\end{array}$ & $\begin{array}{l}\text { Expe } \\
\text { rime } \\
\text { ntal }\end{array}$ & $\begin{array}{l}\text { ANS } \\
\text { YS }\end{array}$ \\
\hline \multirow[b]{2}{*}{$\begin{array}{l}\text { M } \\
20\end{array}$} & $\mathrm{CC}$ & 80.50 & 70.20 & 82.50 & 74.30 & 16.00 & 15.60 \\
\hline & $\begin{array}{c}\mathrm{CC} \\
\text { (RW } \\
\text { GFA) } \\
\end{array}$ & 82.50 & 73.80 & 85.50 & 77.00 & 17.00 & 16.00 \\
\hline \multirow[b]{2}{*}{$\begin{array}{l}\text { M } \\
40\end{array}$} & $\mathrm{CC}$ & 80.00 & 72.00 & 85.00 & 76.80 & 22.00 & 20.10 \\
\hline & $\begin{array}{c}\mathrm{CC} \\
\text { (RW } \\
\text { GFA) }\end{array}$ & $\begin{array}{c}105.0 \\
0\end{array}$ & 97.30 & $\begin{array}{c}107.5 \\
0\end{array}$ & 98.60 & 25.00 & 22.40 \\
\hline \multirow[b]{2}{*}{$\begin{array}{l}M \\
60\end{array}$} & $\mathrm{CC}$ & 92.50 & 82.40 & 95.00 & 80.20 & 27.00 & 25.20 \\
\hline & $\begin{array}{c}\mathrm{CC} \\
(\mathrm{RW} \\
\mathrm{GFA})\end{array}$ & $\begin{array}{c}122.5 \\
0\end{array}$ & $\begin{array}{c}113.4 \\
0\end{array}$ & $\begin{array}{c}125.0 \\
0\end{array}$ & $\begin{array}{c}110.3 \\
0\end{array}$ & 29.00 & 27.70 \\
\hline
\end{tabular}

\section{RESULTS AND DISCUSSIONS}

Mechanical strength of various grades of $\mathrm{CC}$ and RWGFA concrete results are obtained. The chemical properties of recycled waste glass fine aggregate are similar to the properties of sand and alumina is less than $1 \%$ in RWGFA. The behaviour of non absorption water, the mechanical properties of RWGFA concrete cubes are marginally higher strength than conventional cement concrete. The mechanical strength of cubes of seven days and twenty eight days are compared. It is shown in Figure 26 to 28. Flexural behaviour of various grade mix, RWGFA, CC beams are tabulated previously. Load deflection curves of are shown in diagrams. The failure patterns of the RWGFA concrete beams made with recycled waste glass and cement concrete beams made with river sand are shown and the crack pattern of RWGFA beams is similar to conventional cement concrete beam. The comparison of load deflection curve for RWGFA and CC beams are in Diagram 29.

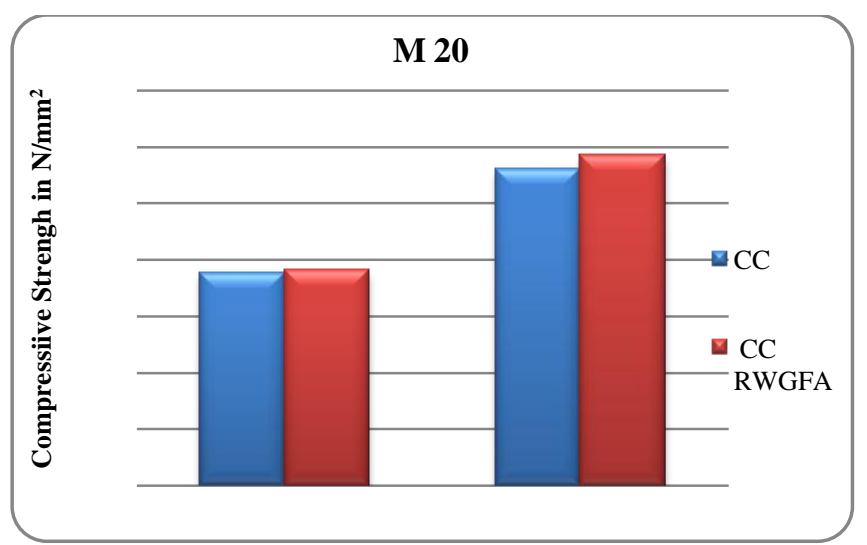

Figure 26 Comparison of M 20 CC and RWGFA Cubes

Published By:

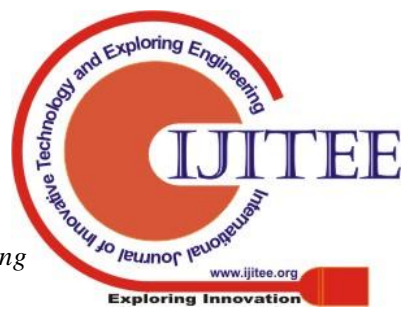




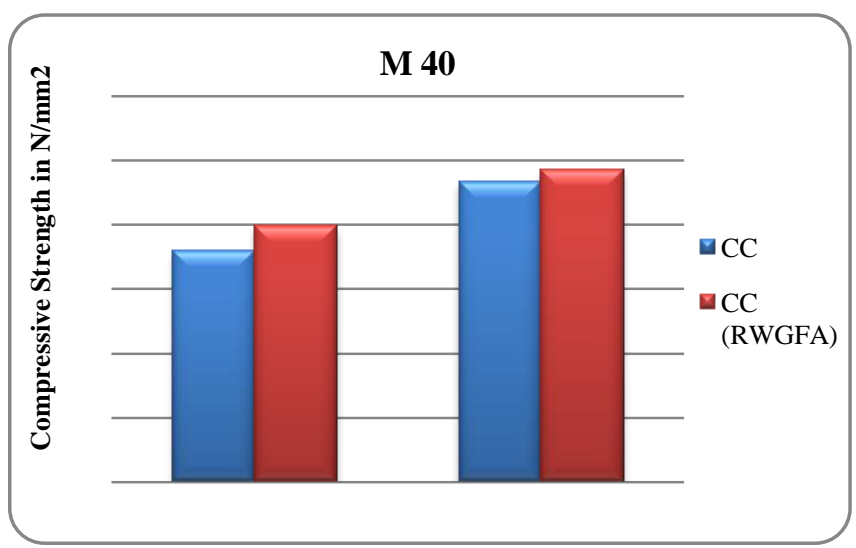

Figure 27 Comparison of M 40 CC and RWGFA Cubes

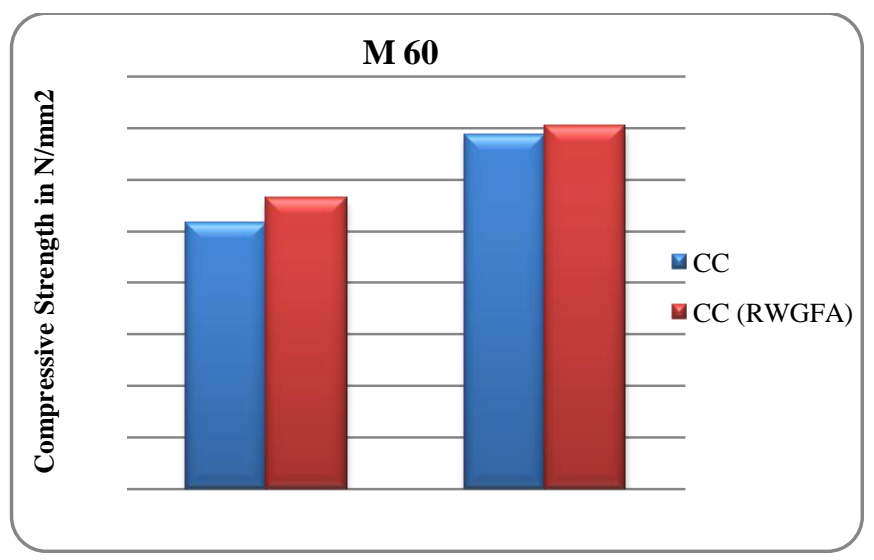

Figure 28 Comparison of M 60 CC and RWGFA Cube

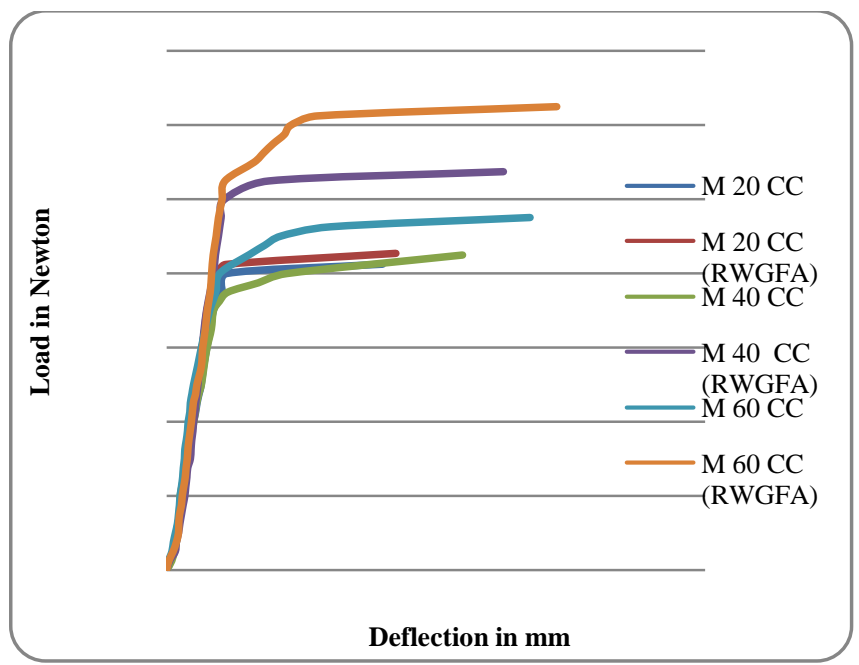

Figure 29 Comparison of Load Deflection Curve for CC and RWGFA Concrete Beams

\section{CONCULUSIONS}

Based on the experiment results, the conclusions are as below.

1. Using recycled glass aggregate in concrete enhances the mechanical strength of all grade mix when compared to conventional concrete using sand.

2. Due to the lower water absorption in glass aggregate concrete, the compressive is increased.

3. The maximum load carrying capability of M 20 grade RWGFA beam is $3 \%$ higher than conventional one.
4. The ultimate load carrying capacity of M 40, M 60 RWGFA concrete beams are having $26 \%$ and $31 \%$ and higher than the conventional beams respectively.

5. The number of cracks and width of the cracks of glass aggregate concrete beams are similar pattern when compared to conventional concrete beams.

6. The load carrying capacity and deflections of all beams obtained using Ansys modeling are showing a maximum of $8 \%$ lower values when compared to experimental values.

\section{REFERENCES}

1. N. Kumarappan, Partial replacement cement using waste glass, IJERT, Vol.2, Issue 10, Oct 2013.

2. BanuPriya, Jostin P. Jose, Use of glass powder asfine aggregate in high strength concrete, IJOSER, Vol.2, Issue 7 July 2014.

\section{BIOGRAPHY}

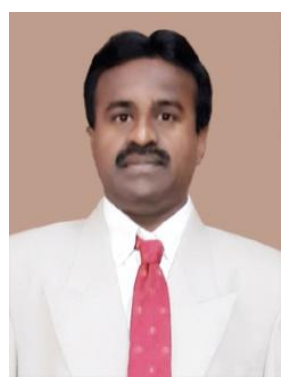

B. Parthiban received his Bachelor Degree and Master Degree in Department of Civil \&Strutural Engineering, Annamalai University. At present, he is pursuing Doctoral Degreee in Structural Engineering in Annamalai University. He had published Seven research papers in UGC Approved Journals. He had presented Two papers in National Conference and Two papers in International Conference. E mail: balaparthi@gmail.com

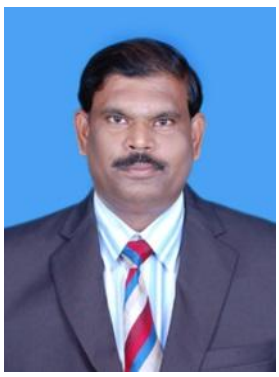

Dr.S.Thirugnanasambandam is presently working as Associate Professor in Annamalai University. He had completed his Master Degree and Doctoral Degree in Annamalai University. He is working in the Department of Civil and Structural Engineering since 1999. Four of his scholars awarded Ph.D., degree and presently guiding seven Ph.D., Scholars. He had published 74 research papers and attended many National and International Conference. His areas of interest are damage assessment and repair of structures. Also, he is familiar in development of Geopolymer Concrete Products.

E mail: agstsai@gmail.com 